\title{
Histopathological study of liver tissue due to methadone consumption and its effect on liver enzymes and inflammatory indices in rat
}

This article was published in the following Dove Press journal:

Drug Design, Development and Therapy

\author{
Mansour Amraei ${ }^{1, *}$ \\ Mahmoud Mohamadpour ${ }^{2, *}$ \\ Mohammad Reza Hafezi \\ Ahmadi $^{3}$ \\ Monireh Azizi ${ }^{4}$ \\ Ahmad Daemi ${ }^{5}$ \\ Mohammad Omidi ${ }^{5}$ \\ Ehsan Shirzadpour ${ }^{2}$ \\ 'Department of Physiology, Faculty of \\ Medicine, Ilam University of Medical \\ Sciences, Ilam, Iran; ${ }^{2}$ Department \\ of Biochemistry, Faculty of \\ Medicine, llam University of Medical \\ Sciences, Ilam, Iran; ${ }^{3}$ Department of \\ Pathobiology, Faculty of Medicine, \\ Ilam University of Medical Sciences, \\ Ilam, Iran; ${ }^{4}$ Department of Anatomy, \\ Faculty of Medicine, Ilam University \\ of Medical Sciences, Ilam, Iran; \\ ${ }^{5}$ Department of Biochemistry, Student \\ Research Committee, Ilam University \\ of Medical Sciences, llam, Iran \\ *These authors contributed equally \\ to this work
}

\begin{abstract}
Background: Methadone (MET)-based treatment is currently one of the best known approaches in the treatment of opioid dependence. It is claimed that MET use exerts adverse effects on the performance of some organs, especially liver. Thus, the present study aims to investigate MET effects on the hepatic tissue as well as its effect on the hepatic enzyme levels and inflammatory markers in rats.
\end{abstract}

Materials and methods: Twenty-eight mature male Wistar rats underwent an 8-week treatment in four equal groups including the control group (an ordinary daily dietary regime) as well as the experimental groups 1, 2, and 3 (an ordinary daily dietary regime and gavage-fed on MET syrup for 5, 20, and $40 \mathrm{mg} / \mathrm{kg}$ body weight per day). Blood samples were collected from all rats in the beginning and end of the study to measure their hepatic enzyme levels and inflammatory markers. In the end, their livers were subjected to histological examinations.

Results: The mean serum levels of hepatic enzymes (alanine aminotransferase, aspartate aminotransferase, and alkaline phosphatase) increased considerably across all the three groups that had received various dosages of $\operatorname{MET}(5,20$, and $40 \mathrm{mg} / \mathrm{kg})$ in the end of the study as compared to the beginning of the study $(P<0.001)$. It was also found that the inflammatory indicators (interleukin-6, tumor necrosis factor-alpha, and C-reactive protein) rose significantly in the groups that had received various dosages of MET in contrast to the control group $(P<0.01, P<0.001$, and $P<0.001$, respectively). The histopathological images of the liver cross-sections revealed dosage-dependent tissue changes in the groups that had received various dosages of MET.

Conclusion: The present study tried to prove the adverse effects of MET in the development of liver damage. Since MET-based treatment is frequently prescribed by physicians for curing the addiction to narcotics, better strategies are required for its correct usage.

Keywords: methadone, hepatic enzymes, inflammatory markers, lipid profile, rat

\section{Introduction}

The term "opioids" refer to natural, semisynthetic, and synthetic compounds with an endogenous origin which interact with opioid receptors. ${ }^{1}$ Opiate abuse and dependence is a complex, multidimensional problem which influences different groups of people and communities. ${ }^{2}$ Its main pharmacological effects include mood changes, agitation, drowsiness, confusional state, fear, insomnia, hallucinations, sedation, respiratory depression, motor incoordination, sweating, euphoria, dysphoria, vomiting, and addiction. ${ }^{3,4}$ To date, opioid agonist therapy with either methadone (MET), buprenorphine, or naltrexone is known to be the most effective treatment for opioid addiction. ${ }^{5,6}$ In comparison with other opioids, MET has useful characteristics including simple route of administration, large oral bioavailability, and a long half-life (an initial
Correspondence: Ehsan Shirzadpour Department of Biochemistry, Faculty of Medicine, Ilam University of Medical Sciences, PO Box 6939I-77I43, llam, Iran Tel +98 8432235745

Fax +988432235723

Email ehsan.shp66@yahoo.com 
half-life of 12-24 hours and a secondary half-life of 55 hours) making outpatient management feasible. ${ }^{6,7}$ Overall, MET is widely used as the first-line replacement therapy for the treatment of opiate-dependent patients. ${ }^{8}$

MET is an opioid of diphenylheptylamine class which is similar in its physiological and analgesic attributes to opium but is not euphoric. It was first developed during World War II and its usefulness in controlling addiction was discovered in the 1960 s..$^{9,10}$ MET has both opioid and nonopioid-related effects: 1) it is the unique effective medication in preventing opioid withdrawal; it binds primarily as full agonist to the opioid receptors and removes or minimizes withdrawal symptoms and thus reduces reliance on heroin; ${ }^{9-11}$ 2 ) it has also proved effective in treating hyperalgesia and neuropathic pain as an N-methyl-D-aspartate receptor; and 3 ) it may have an antidepressant effect since it inhibits the reuptake of noradrenalin and serotonin. ${ }^{12-15}$

MET is taken orally and readily absorbed from the gastrointestinal tract with peak plasma concentrations reaching within $2.5-4.4$ hours. ${ }^{16}$ It is metabolized in the liver and small intestine by several isoforms of CYP/CYP450, and its metabolite is secreted in urine and also (less than 5\%) in feces. ${ }^{1,16}$ Although MET therapy is generally considered to be safe, excessive consumption has been associated with a considerable rise in toxicity and adverse events on memory, information processing, and executive functions. ${ }^{17,18}$ There is a widely held assumption about the adverse effects of MET on liver dysfunction. Some studies have confirmed such adverse effects on patients receiving MET, ${ }^{19,20}$ while no evidence regarding the effects of MET on liver toxicity has been found in others. ${ }^{21,22}$

The most important diagnostic liver enzymes are alanine aminotransferase (ALT), aspartate aminotransferase (AST), and alkaline phosphatase (ALP), which are commonly found in liver cells and released into the bloodstream when the liver is damaged. ${ }^{23}$ In this situation, the levels of hepatic enzymes rise, with these events mostly observed in hepatocellular damage such as alcohol hepatotoxicity and viral hepatitis. $^{23,24}$

The results of various studies have suggested that the immune system is weakened and malfunctions during narcotic use as well as during MET-based addiction withdrawal. ${ }^{25}$ Narcotics can influence opioid receptors extant in lymphocytes and macrophages directly or the central nervous system (CNS) indirectly, thereby affecting the immune system's reactions. ${ }^{26,27}$ Cytokines, which are small proteins acting as the immune system transmitters and causing inflammatory and immunity reactions, are influenced by these substances. ${ }^{28,29}$ Various studies have reported that narcotics use causes secretion of various proinflammatory cytokines including tumor necrosis factor-alpha (TNF- $\alpha$ ) and interlukin-6 (IL-6) ${ }^{30}$ The expression of these cytokines demonstrates the prolonged use of narcotics which has brought about inflammation represented by production of inflammatory factors. ${ }^{31}$

MET can induce biochemical alterations, which may be of major interest in understanding potential toxic effects. ${ }^{1}$ With increasing numbers of physicians prescribing MET to patients and high prevalence of MET, it should be determined whether MET poses any significant risk of hepatotoxicity. Thus, we designed this study to investigate the effect of MET on serum levels of liver enzymes (AST, ALT, and ALP) as well as the level of some inflammatory markers (IL-6, TNF- $\alpha$, and C-reactive protein [CRP]) and to examine histological hepatic damage in male Wistar rats.

\section{Materials and methods}

\section{Animals' grouping and treatment}

Mature male Wistar rats with an average weight of $200 \pm 20 \mathrm{~g}$ were used to perform this empirical research. The animals were kept under standard light, temperature, and humidity conditions in special cages with temperatures equal to $25^{\circ} \mathrm{C} \pm 2^{\circ} \mathrm{C}$ and a 12 -hour light/dark cycle. They were sufficiently nourished with special compact foodstuff and water. The animals were subjected to the abovementioned conditions 1 week before the beginning of the study so that they could become more adapted to the laboratory environment.

Twenty-four mature male Wistar rats were assigned into four groups, each comprising six rats, who were subjected to 8 weeks of experimental protocol. The present study benefited from gavage method and the animals were administered with specific foodstuff as explained below:

1. Group 1 (control): only received an ordinary daily dietary regime.

2. Group 2: received an ordinary daily dietary regime and MET syrup at $5 \mathrm{mg} / \mathrm{kg}$ of body weight.

3. Group 3: received an ordinary daily dietary regime and MET syrup at $20 \mathrm{mg} / \mathrm{kg}$ of body weight.

4. Group 4: received an ordinary daily dietary regime and MET syrup at $40 \mathrm{mg} / \mathrm{kg}$ of body weight.

MET syrup was purchased from Daru Pakhsh Company (methadone $25 \mathrm{mg} / 5 \mathrm{~mL}$ of $250 \mathrm{~mL}$ syrup; Darou Pakhsh Holding Co., Tehran, Iran). and the animals were gavagefed on MET syrup on a daily basis for the aforementioned dosages. To establish identical conditions for the control group and the experimental groups $1-3$, the control group 
was gavage-fed on $2 \mathrm{cc}$ of the drug solvent every day. The treatment lasted for 8 weeks.

\section{Hepatic enzyme levels and inflammatory markers' measurement}

The animals were kept starved for 12 hours before initiating the administration of the dietary regimes as well as after the termination of the study period. Then, blood samples were collected twice (once at the onset of the study at which time blood samples were collected from saphenous vein and another time at the end of the study at which time blood samples were directly taken from the animals' hearts) from all of the rats to measure the intended enzyme levels and markers: once on the first day of treatment initiation and another time at the end of the eighth week. The collected blood samples were kept in serum separation tubes at laboratory temperature for 20 minutes to allow coagulation to take place. Next, serum separation was performed at 2,000 rpm, following which the specimens were centrifuged for 10 minutes. Auto-Analyzer (Technico RA-1000) device was utilized to assess the hepatic enzyme levels (ALT, AST, and ALP) and inflammatory markers (IL-6, TNF- $\alpha$, and CRP).

\section{Histological investigations}

Twelve hours after initiating the treatment and collecting the blood samples, the animals were anesthetized using ether and their livers were removed and kept and fixed in $10 \%$ formalin solution to be subjected to histological examinations. The hepatic tissue was fixed in formalin solution to be dehydrated in consecutive stages using ethanol and after that it was molded in 3.5\% agarose. The tissue embedded blocks were fixed on a tissue slicing device (microtome). Also, sections with $5 \mu \mathrm{m}$ thicknesses were prepared and stained using H\&E. In the end, the slides were observed under light microscope.

\section{Ethics statement}

The experiments were undertaken in complete adherence to the ethical and legal standards specified in the ethical guidelines of Ilam University of Medical Sciences for using laboratory animals. The protocol was also approved by the Ethics committee of this university (IR.MEDILAM. REC.1395.77).

\section{Statistical analysis}

Statistical analysis of the data was conducted using SPSS version 16 . The mean values of variables were presented in the form of mean \pm SEM for each group of rats. To do the mean comparisons of quantitative variables at the beginning and end of the intervention, paired samples $t$-test was employed. Two-way ANOVA was utilized to perform intergroup mean comparisons, and Tukey's follow-up test was employed to perform the mean comparisons between two groups. The significance level for all of the tests was set at $P<0.05$.

\section{Results \\ Liver histopathology}

Figure 1 demonstrates the histopathological images of liver cross-sections stained with $H \& E$ dyes for each of the studied groups. The examinations of the prepared liver cross-sections are indicative of normal tissue structures for the control group rats, for which no signs of inflammation or degeneration in the central venin region and portal space were observed (A1, A2). On the other hand, dosedependent tissue changes were documented for the groups that had received MET. In these groups, reversible hydropic changes as well as macrovesicular fatty changes were seen. Also, some necrotic changes in hepatocytes were observed for the group that had received MET syrup at a dosage of $5 \mathrm{mg} / \mathrm{kg}$ of body weight (B1, B2). The images pertaining to $20 \mathrm{mg} / \mathrm{kg}$ dosage are also indicative of single cell necrosis and portal inflammation $(\mathrm{C} 1, \mathrm{C} 2)$. Tissue changes in the form of confluent necrosis concomitant with ductular proliferation, prolonged inflammation, and lymphoplasmacytic infiltration in the portal space were clearly visible in the rats that had been administered MET syrup at a dosage of $40 \mathrm{mg} / \mathrm{kg}$ of body weight (D1, D2).

\section{Liver enzymes}

The mean values of the hepatic enzymes of the various groups were measured before the beginning of the study. The ANOVA test results indicated that the values of enzymes were almost similar in all the groups and no significant difference was observed between the groups in this regard $(P>0.05)$. Table 1 summarizes the mean values of the hepatic enzymes after the intervention in the studied groups. The results obtained from the comparison of these values suggest that the values of all three enzymes (ALP, AST and ALT) showed significant enhancement in the groups that had received various dosages of MET in comparison to the control group $(P<0.001)$ (Table 1$)$.

The results related to hepatic enzyme measurements before and after the study are presented in Figure 2. As can be seen, the mean serum levels of these enzymes had risen significantly in all the three groups that had been given various dosages of $\operatorname{MET}(5,20$, and $40 \mathrm{mg} / \mathrm{kg})$ at the end of the 

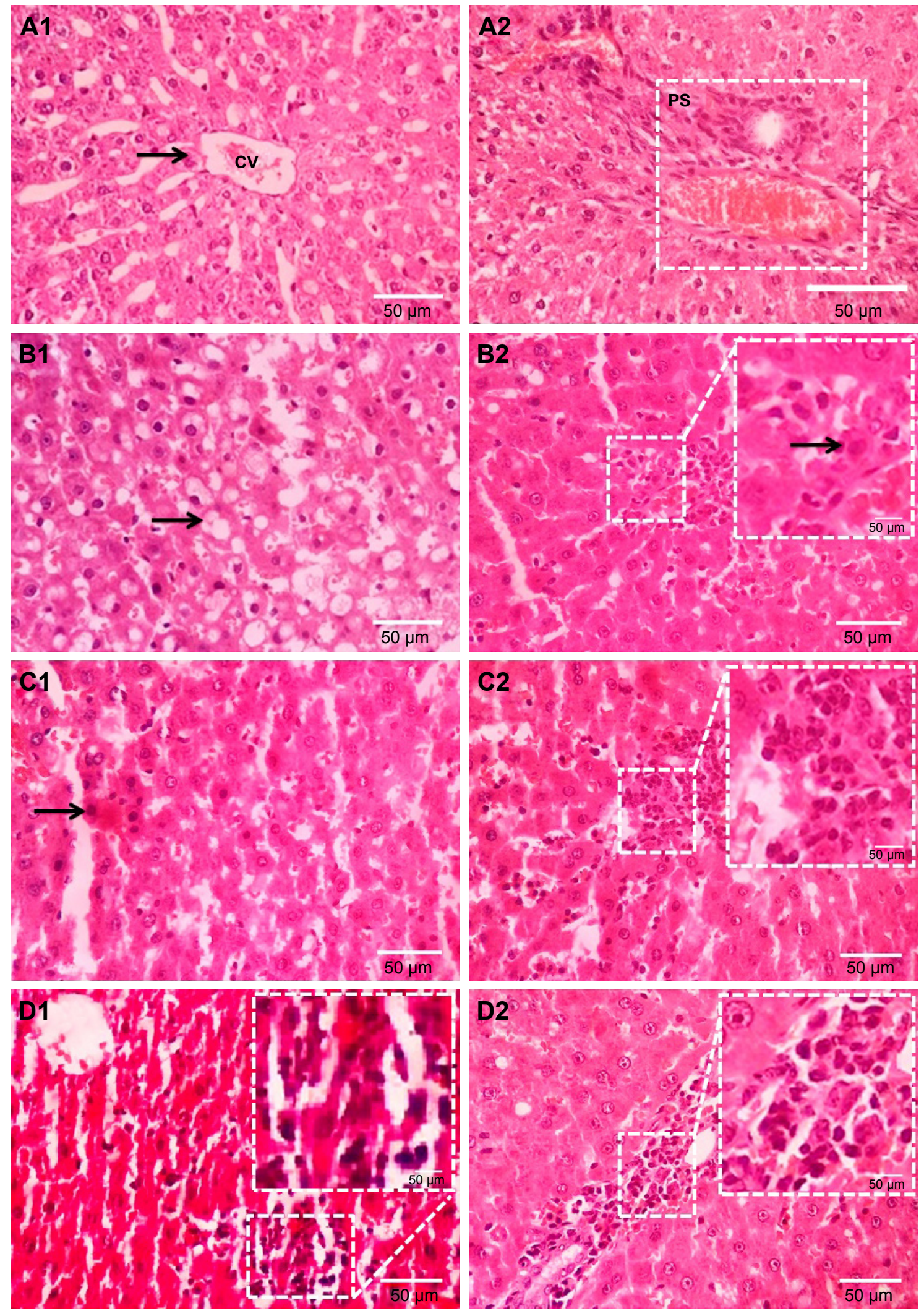

Figure I Histopathological images of H\&E-stained liver cross-sections of the rats from various groups.

Notes: AI,2: control group; BI,2: $5 \mathrm{mg} / \mathrm{kg}$ methadone; CI,2: $20 \mathrm{mg} / \mathrm{kg}$ methadone; DI,2: $40 \mathrm{mg} / \mathrm{kg}$ methadone. Left-side figures (AI, BI, CI, and DI) represent the central veins (CV) of different groups; the right-side figures (A2, B2, C2, and D2) show portal spaces of different groups. Arrows: Al: central vein, BI: macrovesicular fatty change, B2: plasma cell, Cl: single cell necrosis. High magnification, B2: plasma cell, C2 and D2: inflammation of portal spaces, DI: confluent necrosis. Scale bar: $50 \mu \mathrm{m}$. 
Table I Comparison of the mean serum concentration of liver enzymes (ALP, AST, and ALT) in the methadone-receiving groups (with dosages of 5,20 , and $40 \mathrm{mg} / \mathrm{kg}$ ) with control group at the end of the study

\begin{tabular}{|c|c|c|c|c|c|}
\hline $\begin{array}{l}\text { Liver } \\
\text { enzymes }\end{array}$ & $\begin{array}{l}\text { Group I } \\
\text { (control) }\end{array}$ & $\begin{array}{l}\text { Group } 2 \\
\text { (MET } 5 \mathrm{mg} / \mathrm{kg} \text { ) }\end{array}$ & $\begin{array}{l}\text { Group } 3 \\
\text { (MET } 20 \mathrm{mg} / \mathrm{kg} \text { ) }\end{array}$ & $\begin{array}{l}\text { Group } 4 \\
\text { (MET } 40 \mathrm{mg} / \mathrm{kg} \text { ) }\end{array}$ & $\begin{array}{l}P \text {-value } \\
(P<0.05)\end{array}$ \\
\hline ALP (mg/dL) & $168.28 \pm 9.86$ & $246.42 \pm 5.79 * * *$ & $276.14 \pm 6.12^{* * *}$ & $352.85 \pm 7.12 * * *$ & vs control \\
\hline AST (mg/dL) & $|22.00 \pm||.2|$ & $|54.57 \pm| \mid .02 *$ & $227.57 \pm 12.36$ *** & $237.85 \pm|4.9| *$ & vs control \\
\hline ALT (mg/dL) & $67.28 \pm 4.64$ & $107.14 \pm 3.53 *$ & $129.28 \pm 3.54 * * *$ & $135.85 \pm 5.08 *$ & vs control \\
\hline
\end{tabular}

Notes: Data are presented based on mean \pm SD. The mean difference is significant at the 0.05 level $(* P<0.05, * * * P<0.00 \mathrm{I})$.

Abbreviations: ALP, alkaline phosphatase; ALT, alanine aminotransferase; AST, aspartate aminotransferase; MET, methadone.

study as compared to its beginning $(P<0.001)$. The findings suggested that the highest increase in the serum levels of these enzymes was observed in groups receiving higher dosages of MET, respectively, reflecting the dose-dependent effect of the drug (Figure 2).

\section{Inflammatory indicators}

The results of ANOVA test also revealed that the values of all three markers including TNF- $\alpha$, CRP, and IL-6 had significantly risen in the groups that had been administered MET syrup at doses of 5,20 , and $40 \mathrm{mg} / \mathrm{kg}$ of their body weights in contrast to the control group $(P<0.01, P<0.001$, and $P<0.001$, respectively) (Table 2 ).

As can be seen in Figure 3, the mean comparison of the inflammatory markers before and after the intervention in different groups indicates that the mean levels of TNF- $\alpha$, CRP, and IL-6 had not changed significantly at the end of the study in the control group that had only received an ordinary daily dietary regime in comparison to the beginning of the study $(P>0.05)$. However, significant increases were observed for all the three inflammatory markers in the groups that had received MET at 5, 20, and $40 \mathrm{mg} / \mathrm{kg}$ of their body weights $(P<0.01, P<0.001$, and $P<0.001$, respectively) (Figure 3).

\section{Discussion}

Opium dependence is a common problem encountered by various communities, for which maintenance therapy is the method of choice. ${ }^{32}$ MET is a pure opioid receptor agonist that exerts agonistic effects on Mu and Kappa receptors. It has been frequently studied as the oldest, most important, and most widely applied drug of this group of agonists worldwide. ${ }^{33}$ Unfortunately, MET administration is known to exhibit unwanted effects as well. Nowadays, it is important to pay attention to and exercise care in administering and using MET due to the expansion of specialized addiction treatment clinics and the widespread use of MET as an agonist in treating drug abuse. The results of the present study indicated that 8 weeks of MET use significantly changed the liver tissue and elevated the amounts of all three hepatic enzymes, ie, ALP, AST and ALT, in the studied rats. In line with the present study, some studies have shown that abnormality in liver performance is an outcome of MET use. ${ }^{34}$ Also, liver damages have been reported in the individuals who had been taking or misusing heroin, MET, and propoxyphene. Also, different morphological damages were observed in the liver biopsy of the narcotic addicts. ${ }^{35-37}$ Unlike these findings, some investigations have not reported considerable effects of MET use on liver. In this regard, Hosseini et al examined the effect of MET on the hepatic enzymes of rats. Their study indicated that 8 weeks of MET use did not yield a significant effect on hepatic enzymes, ALP, AST, and ALT.$^{38}$ In other studies, researchers have dealt with the effect of MET use on hepatic enzymes of patients undergoing MET treatment. They observed that 24 months of MET use had no significant effect on ALT and AST levels. However, the results showed the significant effect of MET on ALP levels, which might be a sign of cholestatic (stoppage) damage pattern of MET on liver. ${ }^{39}$ The results of another study on 98 addicts undergoing MET-based treatment indicated that the liver performance remained normal even after a year of treatment by MET. ${ }^{40}$ The effects of MET use on hepatic toxicity of the patients were also investigated during a 3-year period of treatment by MET in a study conducted by Kreek et al on 129 heroin addicts. The study observed no sign of liver toxicity following MET use in any of the patients. ${ }^{21}$ The effect of MET therapy on hepatic aminotransferase levels (ALT and AST) was evaluated in a study by McNicholas et al conducted on 175 female addicts during their pregnancy periods. Hepatic enzyme levels were measured once every 4 weeks during pregnancy and once after delivery in the study. The obtained results indicated that MET did not have adverse hepatic effects in treating narcotic-dependent pregnant women. ${ }^{41}$ One reason for such differences in the results might be the type 

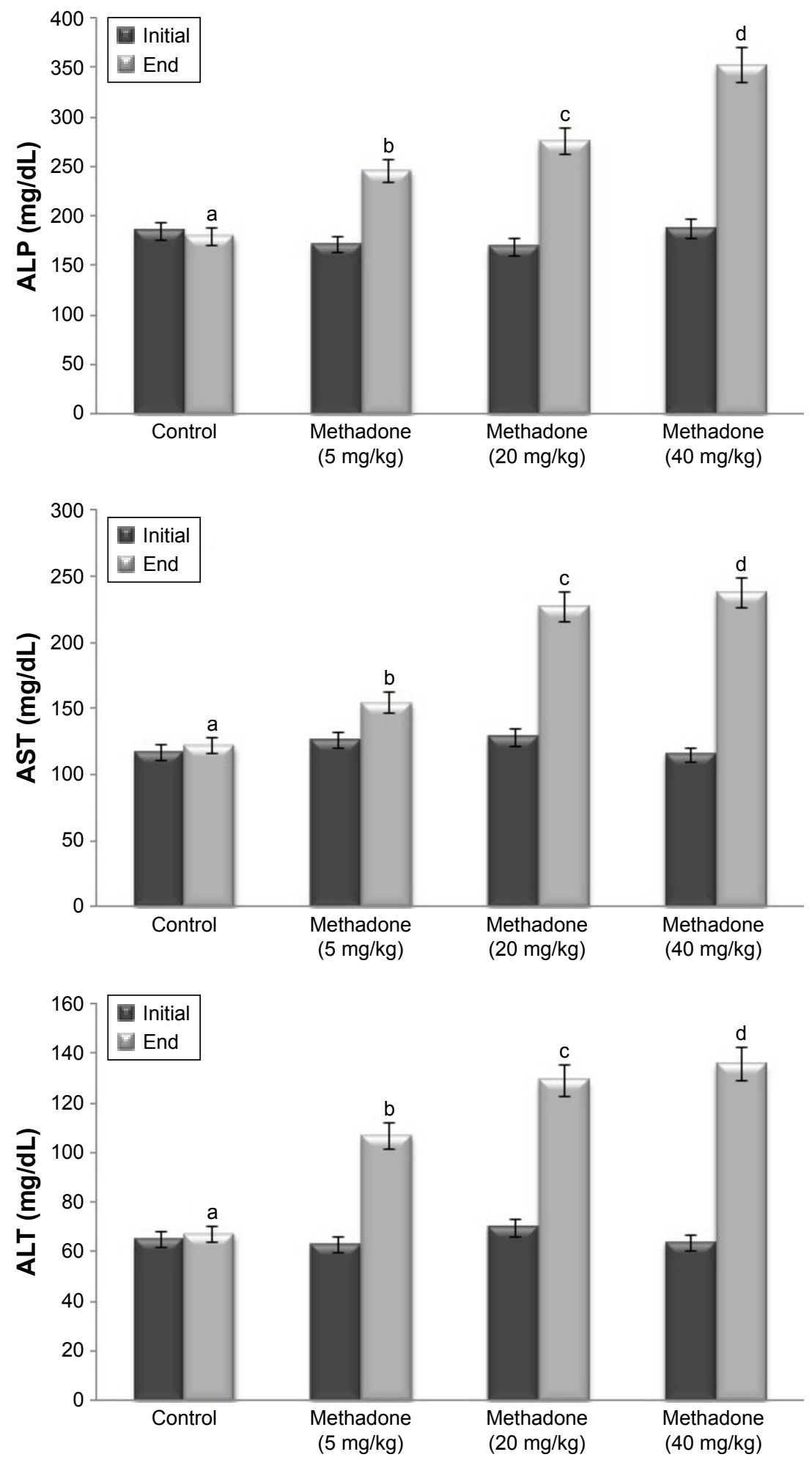

Figure 2 Comparison of the mean serum concentration of liver enzymes (ALP, AST, and ALT) in different groups before and after receiving methadone (5, 20, and $40 \mathrm{mg} / \mathrm{kg})$. Notes: $P$-values for comparisons between the mean rates at the beginning and end of study for different groups are as follows: $a=P>0.05 ; b, c$, and $d=P<0.00 \mathrm{I}$. Abbreviations: ALP, alkaline phosphatase; ALT, alanine aminotransferase; AST, aspartate aminotransferase.

of the study sample size (human and animal), consumption duration, and the applied dosages.

The results of the present study suggest that MET use causes an increase in the inflammatory factors. In the present research, daily administration of MET yielded in a significant increase in the serum levels of IL-6, CRP, and TNF- $\alpha$ in the studied rats. Previous research has reported that the levels of cytokines, particularly proinflammatory cytokines, showed 
Table 2 Comparison of the mean serum concentration of inflammatory factors (TNF- $\alpha$, CRP, and IL-6) in the methadone-receiving groups (with dosages of 5,20 , and $40 \mathrm{mg} / \mathrm{kg}$ ) with control group at the end of the study

\begin{tabular}{|l|l|l|l|l|l|}
\hline $\begin{array}{l}\text { Inflammatory } \\
\text { factors }\end{array}$ & $\begin{array}{l}\text { Group I } \\
\text { (control) }\end{array}$ & $\begin{array}{l}\text { Group 2 } \\
\text { (MET 5 mg/kg) }\end{array}$ & $\begin{array}{l}\text { Group 3 } \\
\text { (MET 20 mg/kg) }\end{array}$ & $\begin{array}{l}\text { Group 4 } \\
\text { (MET 40 mg/kg) }\end{array}$ & $\begin{array}{l}\boldsymbol{P} \text {-value } \\
(\boldsymbol{P}<\mathbf{0 . 0 5})\end{array}$ \\
\hline TNF- $\alpha(\mathrm{pg} / \mathrm{mL})$ & $10.96 \pm 0.18$ & $11.96 \pm 0.20^{* *}$ & $15.88 \pm 0.23^{* * *}$ & $17.52 \pm 0.19 * * *$ & vs control \\
\hline CRP $(\mathrm{ng} / \mathrm{mL})$ & $1.87 \pm 0.06$ & $2.23 \pm 0.09 * *$ & $2.31 \pm 0.12^{* * *}$ & $2.89 \pm 0.12^{* * *}$ & vs control \\
\hline IL-6 $(\mathrm{ng} / \mathrm{L})$ & $3.03 \pm 0.05$ & $3.19 \pm 0.12^{* *}$ & $3.79 \pm 0.16 * * *$ & $3.83 \pm 0.18^{* * *}$ & vs control \\
\hline
\end{tabular}

Notes: Data are presented based on mean \pm SD. The mean difference is significant at the 0.05 level $(* * P<0.0$ I, $* * * P<0.00 \mathrm{I})$.

Abbreviations: CRP, C-reactive protein; IL-6, interleukin-6; MET, methadone; TNF- $\alpha$, tumor necrosis factor-alpha.

an increase following narcotics use in the rats. ${ }^{42,43}$ The performance of the immune system was investigated in addicts undergoing MET treatment in contrast to the control group in a study by Chen et al. They found that the production of proinflammatory factors including IL-1 $\beta$, IL-6, and IL-8 in the group receiving MET was considerably higher than that of the control group subjects. Consistent with the present study, the mentioned study indicated that the production of various levels of TNF- $\alpha$ and IL-6 is directly associated with MET use duration and dosage. ${ }^{44}$ These results suggest that the MET consumption dosage and duration can lead to systemic inflammation.

Studies have revealed that immunity responses, such as IL-6 secretion, were enhanced in human and laboratory specimens following narcotics use. ${ }^{45,46} \mathrm{IL}-6$ production might be instigated via psychological stress in animals, and these cytokines can cause inflammation and neurodegeneration at higher levels. ${ }^{47}$ No significant difference was observed in the plasma levels of the proinflammatory factors in the study conducted by Zajícová et al for investigating the levels of these factors in heroin addicts as compared to their healthy counterparts. ${ }^{48}$ The researchers found that TNF- $\alpha$ is one of the central mediators of tissue inflammation whose levels have been found to significantly rise in CNS following tissue damage and degenerative processes. ${ }^{49,50}$ Some studies have suggested that the levels of plasma cytokines such as TNF- $\alpha$ and IL-8 considerably grow in addicts undergoing MET treatment in contrast to the control group. ${ }^{51}$ These findings suggested that MET use affects the immune system performance of the consumers and might also cause long-term systemic inflammation.

Liver is the largest gland and one of the most important organs of the body that performs a vast array of actions, including protein synthesis, production of materials required for food digestion, as well as changing, storing, and excreting substances. Detoxification of external compounds, drugs, and poisons is one of the most important roles played by the liver. This raises the chance of damage in response to which hepatic diseases may develop. ${ }^{52,53}$ Hepatic diseases are considered as the major factors leading to various conditions and death worldwide, and toxicity due to chemicals is the most important factor involved in it. ${ }^{54}$ Clinical observations have revealed mild to moderate hepatic disorders in longterm MET treatment. ${ }^{55}$

Narcotics are capable of changing hepatic metabolism and can alter the toxicity of the other drugs used. ${ }^{56}$ Narcotics such as propoxyphene, norpropoxyphene, and MET influence the mechanism of action of metabolic intermediates involved in activating or deactivating P-450 cytochrome. ${ }^{57,58}$ These narcotics might influence the toxicity of other chemicals via enhancing or diminishing the hepatic oxidative metabolism depending on the dosage used, thereby altering the balance between toxic and nontoxic metabolic routes. ${ }^{59}$ Furthermore, narcotics might even have hepatic toxicity effects and cause disorder in the liver function when used excessively. ${ }^{60}$ The existence of considerable hepatic damage in rats receiving MET has been amongst the essential findings of the present study. Other studies have also reported hepatic damages and histopathological changes following narcotic use in animals and humans. ${ }^{35,61-63}$ The increase in serum transaminase levels and reduction in hepatic glutathione levels have been observed in a large number of the studies that have dealt with the histopathological effects of narcotics. ${ }^{59}$ Glutathione is a peptide involved in important cell functions such as inactivation of the electrophiles produced during oxidative metabolism. ${ }^{63-65}$ Studies have demonstrated that some narcotics reduce hepatic glutathione levels. ${ }^{66}$ Although glutathione reduction is not per se considered as a criterion of toxicity, the reduction in hepatic glutathione can be a possible sign of hepatic changes resulting from drug abuse.$^{59}$ That is because glutathione is vital for many hepatocellular functions, and reduction in hepatocellular glutathione is associated with reduced viability and membrane leakage when preparing isolated cells. ${ }^{67}$

Researchers have found that the rise in serum levels of transaminase and hepatic damage resulting from misuse of drugs such as acetaminophen and epoxides originate from a reactive electrophilic metabolite. This metabolite is a highly 

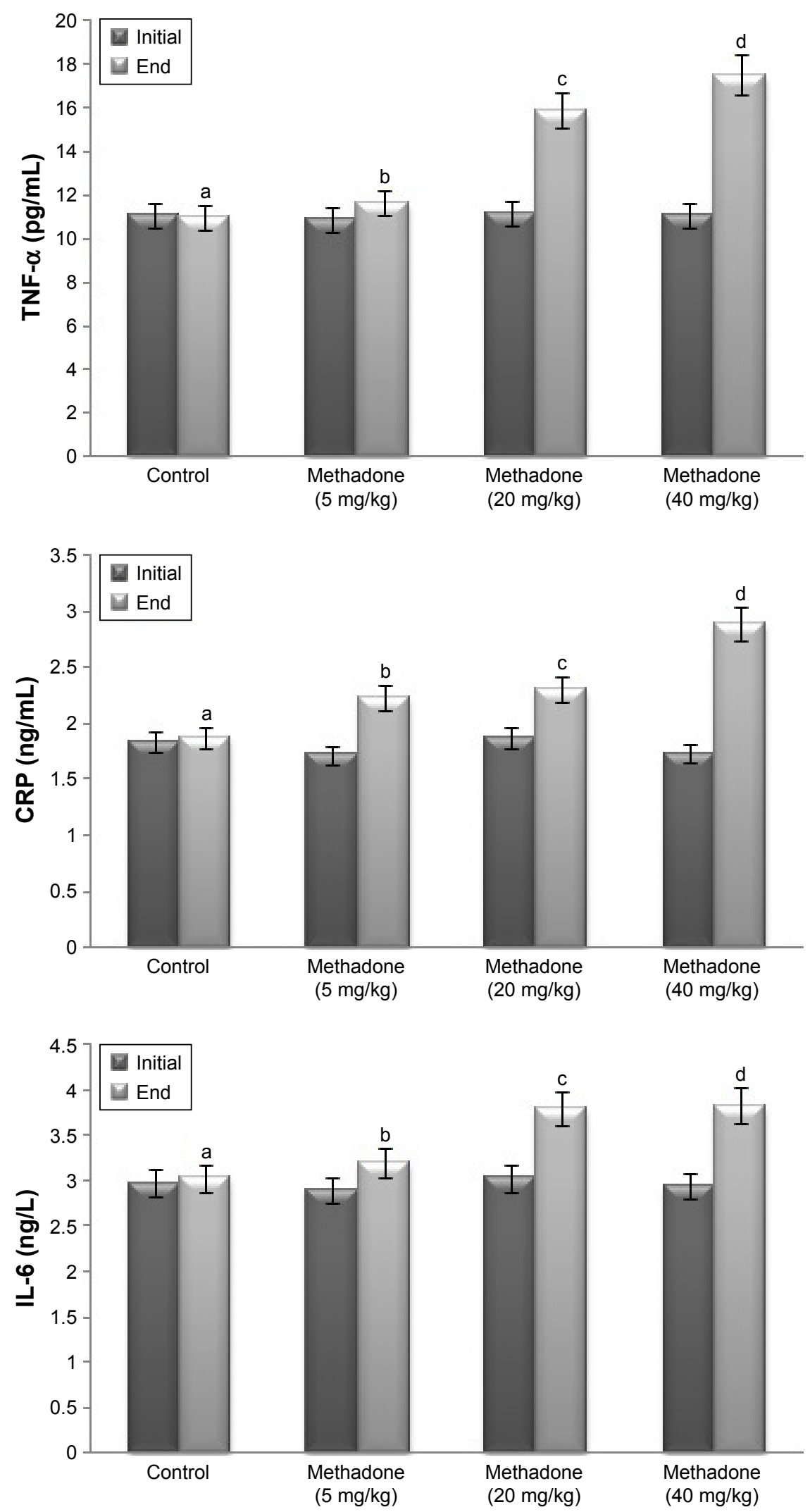

Figure 3 Comparison of the mean serum concentration of inflammatory indicators (TNF- $\alpha$, CRP, and IL-6) in different groups before and after receiving methadone (5, 20, and $40 \mathrm{mg} / \mathrm{kg}$ ).

Notes: $P$-values for comparisons between the mean rates at the beginning and end of study for different groups are as follows: $a=P>0.05 ; b, c$, and $d=P<0.00 \mathrm{I}$.

Abbreviations: CRP, C-reactive protein; IL-6, interleukin-6; TNF- $\alpha$, tumor necrosis factor-alpha. 
reactive and short-lived metabolite that is attached to the macromolecules in hepatocytes, causing hepatocellular damage and death. ${ }^{68,69}$ In the majority of cases, the hepatotoxicity effect of narcotics is a result of the metabolites produced by them. Thompson et al indicated that hepatotoxicity following cocaine injection in rats is due to the effects of some metabolites of cocaine rather than the cocaine itself. ${ }^{70}$ Bioactivation of these compounds to toxic metabolites is a multistage process and is conducted by P-450 cytochrome, resulting in the production of free nitroxyl radicals. ${ }^{71}$ The hepatic damage might arise from the formation of a covalent bond by these radicals with hepatic proteins. ${ }^{72}$ MET is mostly metabolized in liver and its metabolism occurs by hepatic microsomal enzymes, especially P450 system. About $10 \%$ of the administered MET is excreted unchanged while the rest is metabolized, with its metabolites excreted largely through urine and partly through feces. ${ }^{59}$ MET metabolism in the liver might be a possible reason for the hepatotoxic effects of this opioid.

Peroxidation of cell membrane lipids, as a result of free radicals, leading to membrane damage has been reported in some studies for a number of chemicals such as carbon tetrachloride, which in turn might cause losses of intracellular cytosolic components followed by elevations in serum transaminase activity and a decline in hepatocellular glutathione. ${ }^{73,74}$ These incidents can be considered as possible causes of hepatic changes resulting from narcotics use.

In addition, narcotics such as MET cause pulmonary edema and in turn hypoxia, which can eventually exert devastative effects on liver. Some hepatic changes resulting from hypoxia caused by narcotics use have been reported in a study on animals undergoing morphine-based treatment. ${ }^{75}$ The chronic inflammation and lymphoplasmacytic cell infiltration observed might be an outcome of these cells' response to hypoxia.

MET is used in the treatment of heroin abuse and as a strong analgesic thanks to blocking heroin effects when consumed in higher dosages. However, prolonged administration of MET causes dependency and tolerance, and leads to its abuse. Meanwhile, it is also usually overused for its ecstatic effects. $^{76,77}$ Numerous cases of MET side effects have been reported in its users. Among them, dizziness, convulsion and weakness, chronic fatigue, bone and joint pain, sleep disorders, digestive disorders, blood pressure fall, pupillary construction, mouth dryness, headache, urinary symptoms, reduction in sexual desire, ecstasy, respiratory problems, sweating and dermal problems, cardiovascular symptoms, and electrocardiogram disorders (QT segment prolongation) can be mentioned as the most common and most persistent side effects of MET use. ${ }^{78-81}$ There are numerous studies conducted on MET overdose. ${ }^{82-84}$ In a pathological examination of the livers of individuals who had died of MET overdose, positive hepatic pathological findings were observed in $43.9 \%$ of them, including hepatocyte degeneration in $2.4 \%$, hepatic steatosis in $9.8 \%$, hepatocyte necrosis in $24.4 \%$, and more than one pathological finding in $7.3 \% .{ }^{84}$ The study by Darke et al on the individuals who had died of MET overdose indicated a hepatic pathology prevalence rate equal to $80.7 \% .{ }^{85}$ The results of the present study also confirmed the occurrence of hepatic damages in MET users.

\section{Conclusion}

The increase in the demand and consumption of MET, on the one hand, and lack of sufficient preventive measures, on the other hand, have resulted in a serious threat for the society members. Thus, comprehensive management of the disorders resulting from drug abuse is an indispensable necessity. Since MET is now being administered frequently by the physicians as an agonist for the treatment of drug abuse in specialized addiction treatment clinics, paying attention to and exercising care regarding its side effects are of great importance. Considering the side effects and symptoms thereof, plans should be made in regard to the correct use of this drug. Further, according to the findings of the present study which suggest that liver damages develop mostly in a dosagedependent manner, it is therefore necessary to moderate and regulate the therapeutic dosages of MET administered to the patients undergoing treatment with it.

\section{Acknowledgment}

Hereby, we appreciate the support of the Deputy Director of Research and Technology at Ilam University of Medical Sciences.

\section{Disclosure}

The authors report no conflicts of interest in this work.

\section{References}

1. Dinis-Oliveira RJ. Metabolomics of methadone: clinical and forensic toxicological implications and variability of dose response. Drug Metab Rev. 2016;48(4):568-576.

2. Chassin L, Presson CC, Rose J, Sherman SJ. What is addiction? Age-related differences in the meaning of addiction. Drug Alcohol Depend. 2007; 87(1):30-38.

3. Dinis-Oliveira RJ. Licit and ilicit uses of medicines. Acta Med Port. 2014;27(6):755-766.

4. Katzung BG, Masters SB, Basic TAJ. Clinical pharmacology. London, UK: McGraw-Hill Medical; 2012. 
5. Mattick R, Kimber J, Breen C, Davoli M. Buprenorphine maintenance versus placebo or methadone maintenance for opioid dependence. Cochrane Database Syst Rev. 2008;2:CD002207.

6. Brunton LL, Chabner BA, Knollmann BC. Goodman \& Gilman's: The pharmacological basis of therapeutics. New York: McGraw-HillMedical Publishing Division; 2011.

7. Kristensen K, Blemmer T, Angelo HR, et al. Stereoselective pharmacokinetics of methadone in chronic pain patients. Ther Drug Monit. 1996;18(3):221-227.

8. Kaplan MM. Laboratory tests. In: Schiff L, Schiff ER, editors. Diseases of the Liver. 7th ed. Philadelphia: JB Lippincott; 1993:108-144.

9. Johnson BA. Addiction Medicine: Science and Practice. London: Springer; 2011.

10. Johnson RE, Chutuape MA, Strain EC, Walsh SL, Stitzer ML, Bigelow GE. A comparison of levomethadyl acetate, buprenorphine, and methadone for opioid dependence. N Engl J Med. 2000;343(18): $1290-1297$.

11. Barnett P. Comparison of Costs and Utilization among Buprenorphine and Methadone Patients Addiction. Am J Pub Health. 2009;104(6): 982-992.

12. Dole VP, Nyswander M. A medical treatment for diacetylmorphine (heroin) addiction. A clinical trial with methadone hydrochloride. JAMA. 1965;193(8):646-650.

13. Mendlik MT, Uritsky TJ. Treatment of Neuropathic Pain. Curr Treat Options Neurol. 2015;17(12):50.

14. Callahan RJ, Au JD, Paul M, Liu C, Yost CS. Functional inhibition by methadone of N-methyl-D-aspartate receptors expressed in Xenopus oocytes: stereospecific and subunit effects. Anesth Analg. 2004;98(3):653-659.

15. Bush E, Miller C, Friedman I. A case of serotonin syndrome and mutism associated with methadone. J Palliat Med. 2006;9(6):1257-1259.

16. Mouly S, Bloch V, Peoc'h K, et al. Methadone dose in heroin-dependent patients: role of clinical factors, comedications, genetic polymorphisms and enzyme activity. Br J Clin Pharmacol. 2015;79(6):967-977.

17. Sims SA, Snow LA, Porucznik CA. Surveillance of methadone-related adverse drug events using multiple public health data sources. J Biomed Inform. 2007;40(4):382-389.

18. Darke S, Sims J, McDonald S, Wickes W. Cognitive impairment among methadone maintenance patients. Addiction. 2000;95(5):687-695.

19. Walter AJ. Possible hepatotoxic effect of methadone. Can Med Assoc J. 1969;100(5):265-266.

20. Lapierre J. Possible hepatotoxic effect of methadone. Can Med Assoc J. 1969;101(2):113.

21. Kreek MJ, Dodes L, Kane S, Knobler J, Martin R. Long-term methadone maintenance therapy: effects on liver function. Ann Intern Med. 1972;77(4):598-602.

22. Persky VW, Goldfrank LR. Methadone overdoses in a New York City hospital. JACEP. 1976;5(2):111-113.

23. Larson A, Murakami C, Willson R, Stover-Dalton S. The evaluation of abnormal liver function tests and jaundice; 2005. Available from: http://www.uwgi.org/guidelines/Chapters/ch_09/ch09txt.htm. Accessed October 29, 2018.

24. Knight JA. Liver function tests: their role in the diagnosis of hepatobiliary diseases. J Infus Nurs. 2005;28(2):108-117.

25. Garcia JB, Cardoso MG, Dos-Santos MC. Opioids and the immune system: clinical relevance. Rev Bras Anestesiol. 2012;62(5):709-718.

26. Stefano GB, Scharrer B, Smith EM, et al. Opioid and opiate immunoregulatory processes. Crit Rev Immunol. 1996;16(2):109-144.

27. McCarthy L, Wetzel M, Sliker JK, Eisenstein TK, Rogers TJ. Opioids, opioid receptors, and the immune response. Drug Alcohol Depend. 2001;62(2):111-123.

28. Kapasi AA, Gibbons N, Mattana J, Singhal PC. Morphine stimulates mesangial cell TNF-alpha and nitrite production. Inflammation. 2000; 24(5):463-476.

29. American College of Sports Medicine. ACSM's Advanced Exercise Physiology. 2nd ed. Farrell PA, Joyner MJ, Caiozzo V, editors. Philadelphia: Wolters Kluwer Health; 2012; chapter 21-22:512-523.
30. Chen SL, Tao PL, Chu CH, et al. Low-dose memantine attenuated morphine addictive behavior through its anti-inflammation and neurotrophic effects in rats. J Neuroimmune Pharmacol. 2012;7(2):444-453.

31. Greeneltch KM, Kelly-Welch AE, Shi Y, Keegan AD. Chronic morphine treatment promotes specific Th2 cytokine production by murine $\mathrm{T}$ cells in vitro via a Fas/Fas ligand-dependent mechanism. J Immunol. 2005;175(8):4999-5005.

32. Benéitez MC, Gil-Alegre ME. Opioid Addiction: Social Problems Associated and Implications of Both Current and Possible Future Treatments, including Polymeric Therapeutics for Giving Up the Habit of Opioid Consumption. Biomed Res Int. 2017;2017:7120815-7.

33. Kharasch ED. Current Concepts in Methadone Metabolism and Transport. Clin Pharmacol Drug Dev. 2017;6(2):125-134.

34. Kreek MJ. Medical safety and side effects of methadone in tolerant individuals. JAMA. 1973;223(6):665-668.

35. Klein NC, Magida MG. Propoxyphene (Darvon) hepatotoxicity. Am J Dig Dis. 1971;16(5):467-469.

36. Lee TH, Rees PJ. Hepatotoxicity of dextropropoxyphene. Br Med J. 1977;2(6082):296-297.

37. Ostor AG. The medical complications of narcotic addiction. I. Med $J$ Aust. 1977;1(12):410-415.

38. Hoseini SA, Zar A, Hoseini SA, Hassanpour G, Kheirdeh M, Noura M. Effect of Eight Weeks Forced Swimming Training with Methadone Supplementation on Aspartate Aminotransferase, Alanine Aminotransferase, and Alkaline Phosphatase of Rats. J Fasa Uni Med Sci. 2016;6(3):389-398.

39. Eslami-Shahrbabaki M, Haghdoost AA, Mashaiekhi A, Khalili N, Amini-Ranjbar Z, Ghayomi A. Effects of methadone on liver enzymes in patients undergoing methadone maintenance treatment. Addict Health. 2012;4(3-4):111-115.

40. Tashakori A, Heshmati A, Afshari R. Methadone Induced Hepato In: Proceeding of 8th Annual Congress of the Asia Pacific of Medical Toxicology; 2009 Oct 20-22; Beijing, China.

41. McNicholas LF, Holbrook AM, O'Grady KE, et al. Effect of hepatitis $\mathrm{C}$ virus status on liver enzymes in opioid-dependent pregnant women maintained on opioid-agonist medication. Addiction. 2012;107:91-97.

42. Pacifici R, di Carlo S, Bacosi A, Pichini S, Zuccaro P. Pharmacokinetics and cytokine production in heroin and morphine-treated mice. Int J Immunopharmacol. 2000;22(8):603-614.

43. Peng X, Mosser DM, Adler MW, Rogers TJ, Jjjr M, Eisenstein TK. Morphine enhances interleukin-12 and the production of other proinflammatory cytokines in mouse peritoneal macrophages. $J$ Leukoc Biol. 2000;68(5):723-728.

44. Chan YY, Yang SN, Lin JC, Chang JL, Lin JG, Lo WY. Inflammatory response in heroin addicts undergoing methadone maintenance treatment. Psychiatry Res. 2015;226(1):230-234.

45. Beilin B, Shavit Y, Trabekin E, et al. The effects of postoperative pain management on immune response to surgery. Anesth Analg. 2003; 97(3):822-827.

46. Zubelewicz B, Braczkowski R, Renshaw D, Harbuz MS. Central injection of morphine stimulates plasma corticosterone and interleukin (IL)-6 and IL-6R mRNAs in the pituitary and adrenals in adjuvant-induced arthritis. J Biol Regul Homeost Agents. 1999;13(2):103-109.

47. Allan SM, Rothwell NJ. Cytokines and acute neurodegeneration. Nat Rev Neurosci. 2001;2(10):734-744.

48. Zajícová A, Wilczek H, Holán V. The alterations of immunological reactivity in heroin addicts and their normalization in patients maintained on methadone. Folia Biol. 2004;50(1):24-28.

49. Lucas SM, Rothwell NJ, Gibson RM. The role of inflammation in CNS injury and disease. Br J Pharmacol. 2006;147(Suppl 1):S232-S240.

50. Arvin B, Neville LF, Barone FC, Feuerstein GZ. The role of inflammation and cytokines in brain injury. Neurosci Biobehav Rev. 1996;20(3): 445-452.

51. Chen SL, Lee SY, Tao PL, et al. Dextromethorphan attenuated inflammation and combined opioid use in humans undergoing methadone maintenance treatment. $J$ Neuroimmune Pharmacol. 2012;7(4): $1025-1033$ 
52. Sherlock S, Dooley J. Drugs and the liver. In: Sherlock S, Dooley J, editors. Diseases of the Liver and Biliary System. 10th ed. Oxford: Blackwell Science; 1997:337-369.

53. Curtis D, Klaassen PD. Casarett and Doull's Toxicology: The Basic Science of Poison. 7th ed. NewYork: McGraw-Hill Press; 2008:557.

54. Williams R. Global challenges in liver disease. Hepatology. 2006; 44(3):521-526.

55. Novick DM, Kreek MJ, Fanizza AM, Yancovitz SR, Gelb AM, Stenger RJ. Methadone disposition in patients with chronic liver disease. Clin Pharmacol Ther. 1981;30(3):353-362.

56. Gruber VA, McCance-Katz EF, Methadone M-KEF. Methadone, buprenorphine, and street drug interactions with antiretroviral medications. Curr HIV/AIDS Rep. 2010;7(3):152-160.

57. Franklin MR. Inhibition of mixed function oxidations by substrate forming reduced cytochrome $\mathrm{P}-450$ metabolic intermediate complexes. Pharmac Ther A. 1977;2(1):227-245.

58. Roberts SM, Franklin MR. Modification of hepatic microsomal oxidative drug metabolism in rats by the opiate maintenance drugs acetylmethadol, propoxyphene, and methadone. Life Sci. 1979;25(10):845-851.

59. James RC, Freeman RW, Harbison RD. L- $\alpha$-Acetylmethadol-Induced Tissue Alterations in Mice. Drug Chem Toxicol. 1984;7(1):91-112.

60. Gorodetzky CW, Sapira JD, Jasinski DR, Martin WR. Liver disease in narcotic addicts. I. The role of the drug. Clin Pharmacol Ther. 1968; 9(6):720-724.

61. Emmerson JL, Gibson WR, Harris PN, Todd GC, Pierce EC, Anderson RC. Short-term toxicity of propoxyphene salts in rats and dogs. Toxicol Appl Pharmacol. 1971;19(3):452-470.

62. Thureson-Klein A, Wang-Yang J, Ho IK. Lipid accumulation in mouse hepatocytes after morphine exposure. Experientia. 1978; 34(6):773-774.

63. Needham WP, Shuster L, Kanel GC, Thompson ML. Liver damage from narcotics in mice. Toxicol Appl Pharmacol. 1981;58(2):157-170.

64. James RC, Harbison RD. Hepatic glutathione and hepatotoxicity. Effects on cytochrome P-450 complexing compounds SKF525-A, L-a-acetylmethadol (LAAM), norLAAM, and piperonyl butoxide. Biochem Pharmacol. 1982;31(10):1829-1835.

65. James RC, Goodman DR, Harbison RD. Hepatic glutathione and hepatotoxicity: Changes induced by selected narcotics. J Pharmacol Exp Ther. 1982;221(3):708-714.

66. Meister A, Tate SS. Glutathione and related gamma-glutamyl compounds: biosynthesis and utilization. Annu Rev Biochem. 1976;45(1): 559-604

67. Högberg J, Kristoferson A. A correlation between glutathione levels and cellular damage in isolated hepatocytes. Eur J Biochem. 1977;74(1): 77-82.

68. Dahlin DC, Miwa GT, Lu AY, Nelson SD. N-acetyl-p-benzoquinone imine: a cytochrome P-450-mediated oxidation product of acetaminophen. Proc Natl Acad Sci US A. 1984;81(5):1327-1331.

69. James LP, Mayeux PR, Hinson JA. Acetaminophen-induced hepatotoxicity. Drug Metab Dispos. 2003;31(12):1499-1506.
70. Thompson ML, Shuster L, Shaw K. Cocaine-induced hepatic necrosis in mice - the role of cocaine metabolism. Biochem Pharmacol. 1979; 28(15):2389-2395.

71. Nayak PK, Misra AL, Mulé SJ. Physiological disposition and biotransformation of $(3 \mathrm{H})$ cocaine in acutely and chronically treated rats. J Pharmac Exp Ther. 1976;196(3):556-569.

72. Jollow DJ, Mitchell JR, Potter WZ, Davis DC, Gillette JR, Brodie BB. Acetaminophen-induced hepatic necrosis. II. Role of covalent binding in vivo. J Pharmacol Exp Ther. 1973;187(1):195-202.

73. Aniya Y, Anders MW. Alteration of hepatic glutathione S-transferases and release into serum after treatment with bromobenzene, carbon tetrachloride, or N-nitrosodimethylamine. Biochem Pharmacol. 1985; 34(24):4239-4244.

74. Recknagel RO, Glende EA, Dolak JA, Waller RL. Mechanisms of carbon tetrachloride toxicity. Pharmacol Ther. 1989;43(1):139-154.

75. Retz KC, Steele WJ. Mechanism of inhibition of protein synthesis by morphine in rat brain and liver. Mol Pharmacol. 1982;22(3): 706-714.

76. Swartz MK. Opioids: A Pediatric Epidemic. J Pediatr Health Care. 2018;32(2):115-116.

77. Volkow N, Benveniste H, McLellan AT. Use and Misuse of Opioids in Chronic Pain. Annu Rev Med. 2018;69(1):451-465.

78. Langrod J, Lowinson J, Ruiz P. Methadone treatment and physical complaints: a clinical analysis. Int J Addict. 1981;16(5):947-952.

79. Gholami M, Alipoor R, Zareie T, Rezaiean F, Hedayati A. Frequency of Side Effects of Methadone Maintenance Therapy in Patients Referred to Fasa Doctor Shariati Hospital. J Fasa Uni Med Sci. 2015; $5(2): 248-256$.

80. Bonakdaran S, Akbari Rad M, Hasanzadeh Deloie M, Akhoondpoor Manteghi M, Firoozi A. Pediatrican and pediatric residents' knowledge about anaphylaxis in teaching hospitals of Tehran University of Medical Sciences. J Mashhad Med Sci. 2017;60(2):441-449.

81. Reddy S, Hui D, Osta BE, et al. The effect of oral methadone on the QTc interval in advanced cancer patients: a prospective pilot study. J Palliat Med. 2010;13(1):33-38.

82. Eizadi-Mood N, Yaraghi A, Sharifian Z, Feizi A, Hedaiaty M, Sabzghabaee AM. Clinical Presentation and the Outcome of Therapy in a Cohort of Patients with Methadone Toxicity in Iran. Mater Sociomed. 2015;27(4):276-279.

83. Taheri F, Yaraghi A, Sabzghabaee AM, et al. Methadone toxicity in a poisoning referral center. J Res Pharm Pract. 2013;2(3):130-134.

84. Alikhani B, Soleymanpour A, Sabzghabaee AM, Eizadi-Mood N. Demographic, clinical, and Forensics Findings in Deceased Cases of Acute Methadone Poisoning. J Isfahan Med Sch. 2017;35(449):1343-1351.

85. Darke S, Duflou J, Torok M. The comparative toxicology and major organ pathology of fatal methadone and heroin toxicity cases. Drug Alcohol Depend. 2010;106(1):1-6.

\section{Publish your work in this journal}

Drug Design, Development and Therapy is an international, peerreviewed open-access journal that spans the spectrum of drug design and development through to clinical applications. Clinical outcomes, patient safety, and programs for the development and effective, safe, and sustained use of medicines are the features of the journal, which

\section{Dovepress}

has also been accepted for indexing on PubMed Central. The manuscript management system is completely online and includes a very quick and fair peer-review system, which is all easy to use. Visit http://www.dovepress.com/testimonials.php to read real quotes from published authors. 